\title{
Analysis of Green Open Space Requirement in Rappocini Sub-district, Makassar City
}

\author{
Siti Fuadillah A Amin ${ }^{1}$ \\ \{sitifuadillah@unismuh.ac.id $\left.{ }^{1}\right\}$ \\ Universitas Muhammadiyah Makassar ${ }^{1}$
}

\begin{abstract}
In big cities in Indonesia, there is currently an increase in development in urban areas. Increasing urban land use that continues to grow for the construction of urban facilities and infrastructure, including technological, industrial and transportation advancements and settlements. This is generally detrimental to the existence of Green Open Space (RTH) which is often regarded as land that has no economic value. Large cities in Indonesia, such as in Makassar, have Green Open Space (RTH) which is not ideal because it is less than $30 \%$ of the total area. According to data from the Makassar Environment Office (DLH), of the 17,476.02 hectares of Makassar area, the green space is only 2,422 hectares or equal to $13 \%$. This is interesting to do Green Open Space Needs Analysis in the Rappocini sub-district of Makassar City. With the aim of knowing the area of green open space needed and knowing the development of green open space (RTH) in the district of Rappocini. This research was carried out by calculating the standard requirement for Green Open Space in 11 villages in Rappocini District. From this study it was found that the kelurahan had different needs for Green Open Space according to the area with the same standard of $30 \%$ consisting of $20 \%$ public and $10 \%$ private and the Types of Open Space in 11 Sub-districts namely Sports Field, Environmental Park, Office Environmental Park, Green Line, Private RTH (yard) and Roof Garden.
\end{abstract}

Keywords: Green Open Space Requirements, Types of Green Open Space

\section{Introduction}

In the city of Big cities in Indonesia is now experiencing increased development in urban areas. This is in line with the growing population and the needs of the community itself. generally harm the existence of Green Open Space (RTH) which is often regarded as a land that has no economic value [1], [2]. Green Open Space (RTH) in urban areas is part of spatial arrangement of urban areas that have the benefits of life to maintain and maintain the quality of the environment. In the Earth Summit at Rio De Jeneirio, Brazil (1992) and reaffirmed at the Johannesburg, South Africa (2002) Summit that an ideal city has a minimum of $30 \%$ of the total Green Open Space (RTH).[3] Large cities in Indonesia such as in Makassar, has an Open Space Green (RTH) is not ideal because less than $30 \%$ of the total area. According to Environmental Services (DLH) Makassar data, from 17,476.02 hectares of Makassar area, the RTH area is only 2,422 hectares or equal to $13 \%$. In Makassar there are several districts that have a large area of one of them is Rappocini District. Rappocini district has an area of 9,23 $\mathrm{km} 2$ consisting of 11 villages Land Utilization in Rappocini Sub-district according to RTRW 
Kota Makassar is designated as Integrated Settlement Area. Therefore, through this research will be analyzed wide Green Open Space (RTH) needed in Sub Rappocini Makassar City.

In UU no. 26 of 2007, green open space is an elongated / lane and / or clumped area, with more open use, where plants grow, whether naturally occurring or intentionally planted. In this Law is explained about spatial arrangement stating that $30 \%$ of urban area must be RTH consisting of $20 \%$ public and $10 \%$ private [4].

\subsection{Functions, Benefits and type of Green Open Space}

Permendagri No. 1 of 2007 mentioned functions and benefits of Green Open Space (RTH), namely: Urban Open Space Function (RTH) of urban areas are:

1. Safeguarding the existence of urban protected areas;

2. Pollution control and soil, water, and air damage;

3. Germplasm and biodiversity conservation sites;

4. Control of water system; and

5. Aesthetic means of the city

\subsection{The benefits of Green Open Space (RTH) in urban areas are:}

1. Means to reflect regional identity;

2. Research facilities;

3. Active and passive recreational facilities as well as social interactions;

4. Increasing the economic value of urban land;

5. Raising a sense of pride and improving local achievement (Permendagri No. 1 Year 2007).

\subsection{Makassar City Green Open Space}

RTH conditions in Makassar City are still far from 30\% percent according to the law. For this reason, the Makassar City Government refers to the regulations that have been stipulated regarding green space, including the Regional Regulation on Greening, the Regional Regulation on Structuring and Management of Green Open Space, Regional Regulations concerning the Makassar City Spatial Plan for 2015-2034. One of the things that is being done now is the greening program such as garden and vertical garden aisles, as well as green space inventory as a support for green space provision in Makassar City. Implementation of Makassar City Green Open Space includes planning, utilization, supervision and control [5].

\section{Method}

2.1 Location and Time of Research

The research method used is quantitative research methods by conducting field observations. Research location in Rappocini Subdistrict, Makassar City with six (6) months research time.

2.2 Analysis Model

The analysis model uses parameters that can be seen in the table:

Table I

\begin{tabular}{lllll}
\hline Sub-districts & Area (ha) & $\begin{array}{l}\text { Standard Area } \\
\text { RTH }\end{array}$ & $\begin{array}{l}\text { Requirements for green } \\
\text { space }\end{array}$ \\
\hline $\begin{array}{l}\text { 11 Sub-districts in Kec. } \\
\text { Rappocini }\end{array}$ & $\begin{array}{l}\text { Area of each sub } \\
\text { districts }\end{array}$ & $\begin{array}{l}20-30 \% \text { of the } \\
\text { area }\end{array}$ & $\begin{array}{l}\text { Need analysis according to } \\
\text { RTH standards }\end{array}$ \\
\hline
\end{tabular}


To obtain data, the data collection techniques used are:

1. Observation / observation

Observation or observation is a technique of collecting data by observing directly the object or object of research and recording events and behavior in a fair and detailed manner, while the objects observed are the people who become respondents and the community around the research area in general.

2. Interview

Unstructured interviews with respondents and key informants with a view to completing and deepening the results of observations so that they can uncover the problems to be examined.

3. Documentation

Documentation in this study is used to supplement the data that researchers believe are needed to uncover and display the formulation of the problems proposed in the study, such as Open Space that has not been used optimally, the use of open space with makeshift plants without being maintained, there are still many open spaces that have not been functioned as it should be.

\section{Result and Discussion}

\subsection{General Description of Location}

Rappocini Subdistrict is one of 15 sub-districts located in Makassar City. This sub-district has an area of $9.23 \mathrm{~km} 2$ consisting of 10 villages in 2016 and 2017 is divided into 11 villages. Rappocini District borders:

1. North side with Panakkukang District and Manggala District

2. East side with Manggala and Gowa Districts

3. South of Tamalate District, Gowa Regency

4. West of Makassar District, Mamajang District and Tamalate DistrictAuthors and Affiliations

Table 2. Area of Kelurahan in Rappocini Subdistrict

\begin{tabular}{llll}
\hline No. & Nama Kelurahan & Luas Wilayah $\left(\mathrm{Km}^{2}\right)$ & Jumlah KK \\
\hline 1 & Banta-bantaeng & 1,27 & 3.815 \\
2 & Ballaparang & 0,59 & 2.232 \\
3 & Bonto makkio & 0,20 & 991 \\
4 & Buakana & 0,77 & 2.490 \\
5 & Gunung Sari & 1,05 & 4.227 \\
6 & Kassi-kassi & 0,8 & 3.178 \\
7 & Karunrung & 1,52 & 2.049 \\
8 & Mappala & 0,5 & 1.762 \\
9 & Rappocini & 0,38 & 1.576 \\
10 & Tidung & 0,89 & 3.174 \\
11 & Minasa Upa & 1,26 & 2.951 \\
\hline
\end{tabular}

\subsection{Green Open Space Requirements}

In accordance with Law No. 1 of 2007 which explains that in one area, 30\% of the Green Open Space is required from the Area.[6] In the research location in Rappocin sub-district with an area of $9.23 \mathrm{~km} 2$ or 923 ha, Rappocini sub-district requires RTH is $30 \%$ of the total area of 276.9 ha or $2.769 \mathrm{~km} 2$ consisting of $20 \%$ of public RTH and $10 \%$ of private RTH. For each kelurahan located in Rappocini Subdistrict, there is a table below 
Table 3.

\begin{tabular}{llll}
\hline \multicolumn{1}{c}{ Sub-districts } & \multicolumn{1}{c}{ Area (ha) } & Standard Area RTH & $\begin{array}{c}\text { Requirements for green } \\
\text { space }\end{array}$ \\
\hline Banta-bantaeng & 1,27 & $30 \%$ & 0,38 \\
Ballaparang & 0,59 & $30 \%$ & 0,17 \\
Bonto makkio & 0,20 & $30 \%$ & 0,06 \\
Buakana & 0,77 & $30 \%$ & 0,23 \\
Gunung Sari & 1,05 & $30 \%$ & 0,315 \\
Kassi-kassi & 0,8 & $30 \%$ & 0,24 \\
Karunrung & 1,52 & $30 \%$ & 0,456 \\
Mappala & 0,5 & $30 \%$ & 0,15 \\
Rappocini & 0,38 & $30 \%$ & 0,114 \\
Tidung & 0,89 & $30 \%$ & 0,267 \\
\hline
\end{tabular}

3.3 Types of Green Open Space

The available land in each Kelurahan in Rappocini Balla Parang Subdistrict has different functions, however, most are generally dominated by settlements in accordance with the Makassar City Spatial Plan, namely Rappocini Subdistrict, an Integrated Settlement Area. The types of open spaces are found in 11 villages, namely sports fields, environmental parks, office parks, green lanes, private green spaces (yards) and also a roof garden.

For the Perumnas area found in Mappala Village, the green line here looks very good because almost every corridor has green plants and also every house has a private green space. In the type of Green Open Space such as the Environmental Park in some villages such as Bonto Makkio Village, and Tidung Village residents use the vacant land to plant crops that are useful for them and can produce for local residents. Not only that, the type of Green Open Space found in the villages of Ballaparang, Minasaupa and Bonto makkio residents makes a roof garden by planting vines in several aisles, this can also serve as shelter for pedestrians.

Fig 1 types of open spaces

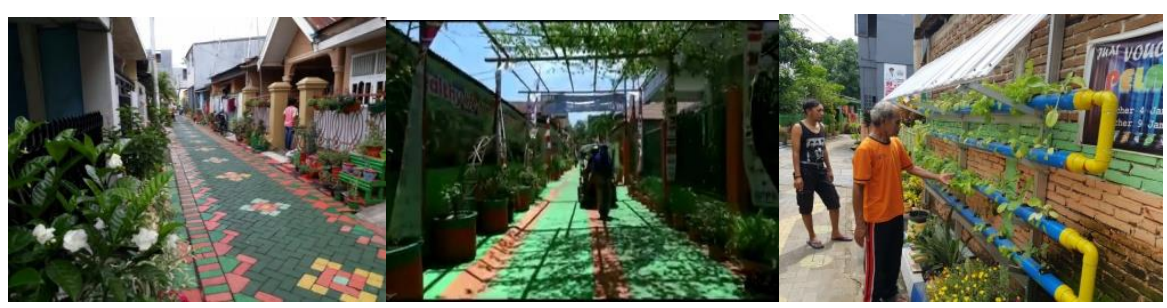

\section{Conclusion}

Based on the results of research conducted on Green Open Space Needs Analysis in the Rappocini sub-district of Makassar City, it was concluded that:

1. For each Overall Green Open Space Requirements have different needs according to their respective area with the same standard of $30 \%$ consisting of $20 \%$ public and $10 \%$ private

2. Types of Open Space found in 11 Sub-Districts namely Sports Field, Environmental Park, Environmental Park Office, Green Line, Private RTH (yard) and Roof Garden. 


\section{References}

[1] A. Prihandono, "Penyediaan Ruang Terbuka Hijau (RTH) Menurut UU No. 26/2007 tentang Penataan Ruang dan Fenomena Kebijakan Penyediaan RTH Di Daerah," $J$. Permukim., vol. 5, no. 1, pp. 13-23, 2010.

[2] V. C. Nugroho, "Evaluasi Ruang Terbuka Hijau di Kecamatan Sleman Kabupaten Sleman," PLANTA Trop. J. Agrosains, vol. 3, no. 2, pp. 114-121, 2015.

[3] Instruction of the Minister of Home Affairs Number 14 of 1988 concerning Green Open Space Arrangement (RTH) in Urban Areas. 1988.

[4] Law No. 26 of 2007 concerning Spatial Planning. 2007.

[5] Minister of Public Works Regulation Number: 05 / PRT / M / 2008 concerning Guidelines for Provision and Utilization of Green Open Space in Urban Areas. 2008.

[6] Permendagri No. 1 of 2007. 2007. 